\title{
A Review: Effect of Rest Interval Duration on the Volume Completed During Resistance Training
}

\author{
Dennis J. Hernandez' \& Young Sub Kwon² \\ ${ }^{1}$ D'Youville College, Buffalo, NY, USA \\ ${ }^{2}$ California Polytechnic University, Humboldt, Arcata, CA, USA \\ Received 20 September 2021 | Revised 15 December 2021 | Accepted 26 December 2021 \\ Open Access Available online at www.johsk.com
}

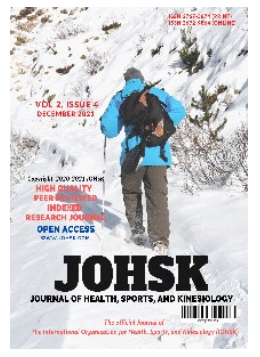

\begin{abstract}
The rest duration between sets is one of the most essential resistance training variables; however, research on the effects of rest intervals between sets has shown inconsistencies on whether short or long rest intervals significantly increase overall performance during resistance training. This literature review aimed to investigate how different rest intervals between sets affect the maintenance of repetitions, training volume, and overall strength gains from resistance exercises in both trained and non-trained individuals. Fifteen original investigations and three textbooks involving the effect of between set rest intervals during resistance training are summarized in this review. The results for the studies interested in repetition maintenance suggested longer rest intervals significantly increased the number of repetitions and helped repetitions stay more consistent throughout sets. Longer rest intervals were also determined to increase training volume but had no significant effect on overall strength gains. Biochemical substrates that provide the catalyst for energy creation can take up to eight minutes to fully resynthesize; therefore, more research is needed on longer rest intervals to see if there are further increases in resistance training performance.
\end{abstract}

Key words: Resistance Training, Training Load, Training Volume, Rest Periods

\section{INTRODUCTION}

Resistance training is commonly associated with sports and the enhancement of sport performance (Kraemer et al., 2002). Furthermore, resistance training can be used for injury prevention, rehabilitation, and in preparation for high-risk jobs such as law enforcement, firefighting, or military service (Jan, Lin, Liau \& Lin, 2008; Weiss, 1991; Willardson, 2006). With a large demographic heavily reliant on training benefits, the understanding of resistance training is imperative to prevent any incidental adverse effects such as a training plateau (Kraemer \& Fleck, 2007). The training plateau is caused by muscular adaptations (obtained from an invariable resistance training program) and impedes further improvements in muscular size, power, and strength. The progressive overload principle can be applied to inhibit or rectify a training plateau by introducing variation that enables further muscular growth and absolute strength (Kraemer \& Fleck, 2007). The progressive overload principle states that in order for a muscle to grow and strength to be increased, the training stimulus must be progressively increased to force the body to adapt to a tension it has never experienced (Kenny, Wilmore, \& Costil, 2015). This principle is essential to acquire further gains in muscular strength and power because it manipulates specific training variables to provide variation in an otherwise invariable training program (Kraemer \& Fleck, 2007). According to the American College of Sports Medicine (2009), training variables include exercise intensity, order of exercise, movement velocity, training frequency, training volume (sets $\times$ repetitions $\times$ load), and the duration of rest between sets. Prior research demonstrates the rest duration between sets as one of the most important variables affecting the repetitions, training volume, and muscular strength (Larson \& Potteiger, 1997; Miranda et al., 2009; Mirzaei, Arazi, \& Saberi, 2008; Willardson, 2006).

The duration of rest between sets, or rest interval (RI), is dependent on the resistance training goals, which include muscular endurance, hypertrophy, power, and strength. The National Strength and Conditioning Association (NSCA) recommends RIs of at least 30 seconds for muscular endurance and a range between 30 to 90 seconds for muscular hypertrophy. In addition, the NSCA recommends a RI between two and five minutes for muscular strength and power (Haff \& Triplett, 2016). Corroborating research also suggests, for 
optimal performance during resistance training, the use of short RIs (30s - 2-min) during muscular endurance and hypertrophy training (the ability to perform more training volume over a shorter amount of time) and long RIs (2-min - 5-min) during muscular power and strength training (strenuous activity requires greater recovery time to replenish energy systems) (Donnelly et al., 2009; Kraemer \& Fleck, 2007). Resistance training, with the goal of muscular strength, requires longer resting periods to resynthesize the depleted energy substrates, adenosine triphosphate (ATP) and phosphocreatine (PCr) (Willardson \& Burkett, 2008). The energy required for muscular strength training is provided from the hydrolysis (breakdown) of ATP; ATP reserves are limited and must be resynthesized for high-tension muscle contractions to continue (Haff \& Triplett, 2016; Weiss, 1991). ATP resynthesis is achieved through the hydrolysis of PCr and is known as the phosphagen energy system (Kenney et al., 2012; Robergs, Ghiasvand, \& Parker, 2004; Weiss, 1991). Muscular strength training primarily relies on the phosphagen energy system and depletes concentrations of PCr drastically to equate ATP concentrations (Baechle \& Earle, 2016; Robergs et al., 2004). After high-intensity exercise, ATP concentrations deplete between $50 \%$ to $60 \%$ and PCr concentrations are nearly eliminated. A comprehensive review of rest duration effects on muscular strength (Weiss, 1991) suggests, the depletion of ATP and PCr concentrations contribute to the fatigue experienced during physical activity. ATP concentrations completely resynthesize between three to five minutes, and $\mathrm{PCr}$ concentrations completely resynthesize within eight minutes following high-intensity exercise (Haff \& Triplett, 2016; Harris et al., 1976).

The length of the RI also affects the removal of proton accumulation caused by high levels of ATP hydrolysis and glycolysis during high-intensity exercise (Mirzaei, Arazi, \& Saberi, 2008; Robergs et al., 2004; Weiss, 1991). A high-intensity resistance exercise, such as a bench press, a squat, or a deadlift requires the body to rely mainly on fast-twitch muscle fibers for energy production. Fast-twitch muscle fibers rely heavily on anaerobic glycolysis and accumulate high levels of hydrogen ions during low-to-moderate intensity resistance performed to failure (Larson \& Potteiger, 1997). The inability to buffer or remove the accumulation of hydrogen ions has been shown to lower intracellular $\mathrm{pH}$, which results in metabolic acidosis and muscle fatigue (Robergs et al., 2004). At low pH values (muscle acidosis), muscle contraction shortening-velocity and the peak isometric force decreases significantly (Larson \& Potteiger, 1997). Other research also suggests that increased hydrogen ion concentration may be the main contributor to reduced force production, which is necessary for eccentric and concentric muscle contraction to continue during high-intensity exercise (Kramer \& Fleck, 2007; Larson \& Potteiger, 1997; Robergs et al., 2004).

The purpose of this investigation (1) was to summarize studies describing RIs effect on the maximum number and sustainability of repetitions, training volume and overall strength gains and (2) to propose that the application of longer RIs between intense exercise bouts may decrease muscle fatigue, and potentially improve the resistive exercise training responses.

\section{METHOD}

\section{Literature Search}

Relevant research was selected using Pubmed, Sports medicine research electronic database (SPORTDiscus), Medicine \& Science in Sports \& Exercise (MSSE) and Journal of Strength and Conditioning Research (JSCR), searching journal articles and reference lists, and World Wide Web searches using Google Research engine identifying pertinent databases and online journals. Of the thirty-five original studies, two abstracts, and three textbooks were initially focused on the effect of between-set RIs during resistance training, specifically using the following terms: fitness testing, rest interval, rest period, recovery, recover-time, training volume, and strength training. Fifteen original studies and three textbooks were fully reviewed. Table 1 to Table 4 summarize studies describing RIs effect on the maximum number and sustainability of repetitions, training volume and overall strength gains.

\section{RESULTS}

\section{Maximal Number and Sustainability of Repetitions}

The ability to sustain repetitions throughout sets increases the maximum number of repetitions performed during a bout of exercise (Willardson and Burkett, 2005). Greater sums of repetitions acutely increase training volume (repetitions $\times$ sets $\times$ load) and chronically increase muscular strength (Kraemer, 1997). Heavy training loads place a greater metabolic demand on the body and negatively affect repetition performance (Mirzaei et al., 2008; Willardson \& Burkett, 2008). Increasing the training load decreases energy substrates (ATP and PCR) and increases metabolic waste $\left(\mathrm{H}^{+}\right)$; thus, impeding necessary chemical reaction pathways that assist in the transformation of chemical energy into mechanical energy (Kraemer \& Fleck, 2007). Previous RI research was primarily concerned with the effect of heavier training loads on repetition performance; specifically, how age, training status, RI method, or exercise type are affected by between-set RI manipulation.

A study by Faigenbaum et al. (2008) was the first to research the effects of age and RI duration on lifting performance in a group of resistance trained males that consisted of: 12 boys, 13 teens, and 17 men. The study used a randomized crossover design to test the effects of one, two, and three-minute RIs on the number and sustainability of repetitions completed during three sets of bench pressing using a ten-repetition maximum (RM) load. The findings indicated that for all ages and all intervals, repetitions completed during each set significantly decreased as sets progressed; however, boys and teens had a less pronounced decrease in lifting performance (due to their ability to resist fatigue) compared to men (Table 1). Men's lifting performance declined significantly from an average of ten repetitions 
during the first set, to an average six repetitions during the third set. This study concluded that men would benefit the most from longer RIs and a minimum of three minutes of rest between sets may be needed to sustain repetitions.

Table 1. Repetition Sustainability Throughout Sets Using Various Rest Intervals

\begin{tabular}{|c|c|c|c|c|c|c|c|}
\hline Study & Load & $\begin{array}{l}\text { Exercise \& } \\
\text { Rest Intervals }\end{array}$ & Set 1 & Set 2 & Set 3 & Set 4 & Set 5 \\
\hline Faigenbaum et al. (2008) & $75 \%$ of $1 \mathrm{RM}$ & Bench Press & & & & & \\
\hline \multirow[t]{3}{*}{ Men's Values } & & $1 \mathrm{~min}$ & $10.0 \pm 0.0^{2,3}$ & $5.7 \pm 2.4^{3}$ & $2.7 \pm 1.5$ & & \\
\hline & & $2 \min$ & $10.0 \pm 0.0^{2,3}$ & $7.2 \pm 2.2$ & $4.2 \pm 2.2$ & & \\
\hline & & $3 \mathrm{~min}$ & $10.0 \pm 0.0^{3}$ & $7.9 \pm 2.7$ & $6.0 \pm 2.8$ & & \\
\hline \multirow{3}{*}{ Teens' Values } & & $1 \mathrm{~min}$ & $10.0 \pm 0.0^{3}$ & $9.5 \pm 1.4^{3}$ & $7.4 \pm 2.6$ & & \\
\hline & & $2 \min$ & $10.0 \pm 0.0^{3}$ & $9.3 \pm 1.4$ & $8.5 \pm 2.2$ & & \\
\hline & & $3 \min$ & $10.0 \pm 0.0$ & $9.8 \pm 0.8$ & $9.1 \pm 1.8$ & & \\
\hline \multirow[t]{3}{*}{ Boys' Values } & & $1 \mathrm{~min}$ & $10.0 \pm 0.0^{3}$ & $9.2 \pm 1.4$ & $8.7 \pm 2.1$ & & \\
\hline & & $2 \min$ & $10.0 \pm 0.0$ & $10.0 \pm 0.0$ & $9.6 \pm 1.0$ & & \\
\hline & & $3 \min$ & $10.0 \pm 0.0$ & $10.0 \pm 0.0$ & $10.0 \pm 0.0$ & & \\
\hline \multirow[t]{3}{*}{ Evangelista et al. (2011) } & $40 \%$ of $M V C$ & Bicep curl & & & & & \\
\hline & & $1 \mathrm{~min}$ & $20.0 \pm 1.5^{2,3}$ & $9.0 \pm 0.7^{3}$ & $7.0 \pm 1.3$ & & \\
\hline & & $3 \mathrm{~min}$ & $24.0 \pm 1.7^{2,3}$ & $14.0 \pm 1.1^{3}$ & $10.0 \pm 0.7$ & & \\
\hline \multirow[t]{16}{*}{ Miranda et al. (2009) } & 8RM & Barbell bench press & & & & & \\
\hline & & $1 \mathrm{~min}$ & $8.4 \pm 0.2^{2,3}$ & $6.4 \pm 0.5^{3}$ & $4.2 \pm 0.6$ & & \\
\hline & & $3 \mathrm{~min}$ & $8.3 \pm 0.2^{3}$ & $7.3 \pm 0.5$ & $5.9 \pm 1.0$ & & \\
\hline & & Inclined bench press & & & & & \\
\hline & & $1 \mathrm{~min}$ & $5.0 \pm 0.7^{3}$ & $3.9 \pm 0.7$ & $3.3 \pm 0.5$ & & \\
\hline & & $3 \mathrm{~min}$ & $7.3 \pm 0.5^{3}$ & $6.6 \pm 0.5$ & $6.1 \pm 0.7$ & & \\
\hline & & Peck deck fly & & & & & \\
\hline & & $1 \mathrm{~min}$ & $4.6 \pm 0.8$ & $3.8 \pm 0.7$ & $3.3 \pm 0.8$ & & \\
\hline & & $3 \mathrm{~min}$ & $6.8 \pm 0.4$ & $5.9 \pm 0.7$ & $5.3 \pm 0.8$ & & \\
\hline & & Barbell lying triceps & & & & & \\
\hline & & extension & & & & & \\
\hline & & $1 \mathrm{~min}$ & $6.5 \pm 0.9^{2,3}$ & $4.9 \pm 0.9$ & $3.4 \pm 1.0$ & & \\
\hline & & $3 \mathrm{~min}$ & $7.3 \pm 0.7^{3}$ & $6.6 \pm 0.7$ & $6.0 \pm 0.7$ & & \\
\hline & & Triceps pushdown & & & & & \\
\hline & & $1 \mathrm{~min}$ & $4.6 \pm 0.6^{2,3}$ & $3.1 \pm 0.8^{3}$ & $2.0 \pm 0.7$ & & \\
\hline & & $3 \mathrm{~min}$ & $6.1 \pm 0.7^{3}$ & $5.3 \pm 0.7$ & $4.9 \pm 0.6$ & & \\
\hline \multirow[t]{18}{*}{ Rodrigues et al. (2012) } & $80 \%$ of $1 R M$ & Barbell bench press & & & & & \\
\hline & & $1 \mathrm{~min}$ & $5.8 \pm 2.3^{2,3}$ & $3.6 \pm 1.5$ & $2.8 \pm 1.2$ & & \\
\hline & & $3 \mathrm{~min}$ & $6.9 \pm 2.5^{2,3}$ & $4.7 \pm 1.7$ & $4.1 \pm 1.8$ & & \\
\hline & & $\begin{array}{l}\text { Machine lat pull } \\
\text { down }\end{array}$ & & & & & \\
\hline & & $1 \mathrm{~min}$ & $6.9 \pm 2.0^{2,3}$ & $3.6 \pm 1.1$ & $2.9 \pm 1.0$ & & \\
\hline & & $3 \mathrm{~min}$ & $7.4 \pm 1.9^{2,3}$ & $6.2 \pm 1.3^{3}$ & $4.4 \pm 1.5$ & & \\
\hline & & Seated machine & & & & & \\
\hline & & shoulder press & & & & & \\
\hline & & $1 \mathrm{~min}$ & $3.7 \pm 1.9^{2,3}$ & $2.1 \pm 1.6$ & $1.3 \pm 1.1$ & & \\
\hline & & $3 \mathrm{~min}$ & $4.5 \pm 2.7^{2,3}$ & $2.7 \pm 1.8$ & $2.3 \pm 1.7$ & & \\
\hline & & Machine triceps & & & & & \\
\hline & & extension & & & & & \\
\hline & & $1 \mathrm{~min}$ & $8.3 \pm 2.9^{2,3}$ & $5.3 \pm 1.5^{3}$ & $3.8 \pm 1.0$ & & \\
\hline & & $3 \min$ & $9.9 \pm 2.7^{2,3}$ & $7.6 \pm 2.5$ & $6.4 \pm 2.6$ & & \\
\hline & & Free weight standing & & & & & \\
\hline & & bicep curl & & & & & \\
\hline & & $1 \mathrm{~min}$ & $5.2 \pm 1.7^{2,3}$ & $2.5 \pm 1.0$ & $1.9 \pm 0.9$ & & \\
\hline & & $3 \mathrm{~min}$ & $5.6 \pm 1.6^{2,3}$ & $4.4 \pm 1.2^{3}$ & $3.1 \pm 1.1$ & & \\
\hline
\end{tabular}

Note. The superscript numbers designate significant difference in relation to the indicated set $(\mathrm{P}<0.05)$. $\mathbf{H R}=$ Heart rate. $\mathbf{M V C}=$ maximum velocity contraction. $\mathbf{R M}$ $=$ Repetition maximum. 
Table 1. Repetition Sustainability Throughout Sets Using Various Rest Intervals (continued)

\begin{tabular}{|c|c|c|c|c|c|c|c|}
\hline Study & Load & $\begin{array}{l}\text { Exercise \& } \\
\text { Rest Intervals }\end{array}$ & Set 1 & Set 2 & Set 3 & Set 4 & Set 5 \\
\hline \multirow[t]{12}{*}{ Monteiro et al. (2013) } & $80 \%$ of $1 R M$ & Bench press & & & & & \\
\hline & & Ratio $1: 3$ & $12.9 \pm 3.6^{2,3,4,5}$ & $10.2 \pm 3.8^{3,4,5}$ & $6.3 \pm 3.1^{4,5}$ & $4.6 \pm 2.6$ & $3.8 \pm 2.2$ \\
\hline & & Ratio 1:5 & $12.3 \pm 4.0^{2,3,4,5}$ & $9.9 \pm 3.6^{3,4,5}$ & $7.6 \pm 3.6^{4,5}$ & $5.9 \pm 3.1$ & $4.6 \pm 2.6$ \\
\hline & & Ratio 1:7 & $12.4 \pm 3.7^{2,3,4,5}$ & $10 . \overline{9} \pm 3.7^{3,4,5}$ & $8.6 \pm 3.4^{4,5}$ & $6.7 \pm 3.0$ & $5.6 \pm 2.6$ \\
\hline & & $\begin{array}{l}\text { Progressive: } \\
1: 3-1: 5-1: 7-1: 9\end{array}$ & $12.5 \pm 4.0^{2,3,4,5}$ & $10.2 \pm 4.0^{3,4,5}$ & $7.9 \pm 3.5^{5}$ & $6.9 \pm 3.1$ & $6.2 \pm 2.6$ \\
\hline & & Fixed: 2 min & $13.5 \pm 4.1^{2,3,4,5}$ & $11.1 \pm 4.5^{3,4,5}$ & $8.7 \pm 4.2^{5}$ & $7.3 \pm 3.4$ & $6.0 \pm 2.7$ \\
\hline & & Triceps extension & & & & & \\
\hline & & Ratio 1:3 & $12.6 \pm 2.9^{2,3,4,5}$ & $9.9 \pm 1.8^{3,4,5}$ & $7.3 \pm 2.1^{4,5}$ & $5.7 \pm 1.8$ & $4.4 \pm 1.6$ \\
\hline & & Ratio 1:5 & $12.1 \pm 3.9^{2,3,4,5}$ & $10.6 \pm 3.3^{3,4,5}$ & $8.5 \pm 2.4^{5}$ & $7.2 \pm 2.3^{5}$ & $5.6 \pm 2.0$ \\
\hline & & Ratio 1:7 & $12.9 \pm 3.9^{3,4,5}$ & $11.8 \pm 3.2^{3,4,5}$ & $9.6 \pm 3.2^{4,5}$ & $8.1 \pm 2.8^{5}$ & $6.2 \pm 2.3$ \\
\hline & & $\begin{array}{l}\text { Progressive: } \\
\text { 1:3-1:5-1:7-1:9 }\end{array}$ & $13.2 \pm 3.1^{2,3,4,5}$ & $11.1 \pm 3.8^{3,4,5}$ & $9.1 \pm 3.3^{5}$ & $8.9 \pm 2.9^{5}$ & $8.1 \pm 2.7$ \\
\hline & & Fixed: 2 min & $12.4 \pm 3.7^{2,3,4,5}$ & $10.8 \pm 3.5^{3,4,5}$ & $9.1 \pm 3.4^{4,5}$ & $7.7 \pm 2.8$ & $6.7 \pm 2.1$ \\
\hline \multirow[t]{4}{*}{ Larson \& Potteiger (1997) } & $85 \%$ of $10 \mathrm{RM}$ & Squat & & & & & \\
\hline & & Post HR & $15.7 \pm 0.7^{2,3,4}$ & $10.6 \pm 0.5^{3,4}$ & $8.8 \pm 0.4^{4}$ & $7.9 \pm 0.6$ & \\
\hline & & $3 \mathrm{~min}$ & $15.5 \pm 0.6^{2,3,4}$ & $10.7 \pm 0.7^{3,4}$ & $8.1 \pm 0.4^{4}$ & $6.5 \pm 0.5$ & \\
\hline & & Ratio 1:3 & $15.6 \pm 0.7^{2,3,4}$ & $10.9 \pm 0.8^{3,4}$ & $8.3 \pm 0.6^{4}$ & $6.8 \pm 0.6$ & \\
\hline \multirow[t]{4}{*}{ Richmond \& Godard (2004) } & $75 \%$ of $1 R M$ & Bench press & & & & & \\
\hline & & $1 \mathrm{~min}$ & $11.9 \pm 2.5^{2}$ & $5.5 \pm 2.2$ & & & \\
\hline & & $3 \mathrm{~min}$ & $11.5 \pm 2.2^{2}$ & $8.3 \pm 2.6$ & & & \\
\hline & & $5 \mathrm{~min}$ & $11.5 \pm 2.3^{2}$ & $9.7 \pm 2.4$ & & & \\
\hline \multirow[t]{4}{*}{ Mirzaeli, Arazi, \& Saberi (2008) } & $90 \%$ of $1 R M$ & Bench press & & & & & \\
\hline & & $1.5 \mathrm{~min}$ & $4.4 \pm 0.7^{2,3,4}$ & $3.2 \pm 0.6^{3,4}$ & $2.2 \pm 0.6^{4}$ & $1.4 \pm 0.6$ & \\
\hline & & $2.5 \mathrm{~min}$ & $4.5 \pm 0.7^{2,3,4}$ & $3.8 \pm 0.9^{3,4}$ & $3.1 \pm 0.7^{4}$ & $2.5 \pm 0.8$ & \\
\hline & & $4 \mathrm{~min}$ & $4.5 \pm 0.7^{2,3,4}$ & $4.4 \pm 0.6^{3,4}$ & $3.8 \pm 0.9^{4}$ & $3.4 \pm 0.6$ & \\
\hline
\end{tabular}

Note. The superscript numbers designate significant difference in relation to the indicated set $(\mathrm{P}<0.05)$. $\mathbf{H R}=$ Heart rate. $\mathbf{M V C}=$ maximum velocity contraction. $\mathbf{R M}$ = Repetition maximum.

Research conducted by Evangelista, Pereira, Hackney, and Machado (2011) used 28 healthy untrained-men to test the effects of one and three-minute RI on the number of repetitions performed during three sets of a bicep curl. The bicep curl load was determined using $40 \%$ of the subject's maximal voluntary isometric contraction strength (MVC) measured by electromyography (EMG). The results indicated that neither RI was successful at sustaining repetitions throughout sets (Table 1). A similar study used twenty untrained-male subjects with one and three-minute RIs between sets but tested five upper-body exercises using $80 \%$ of subject's $1 \mathrm{RM}$ load. The results showed a significant reduction in repetitions for both RI groups, particularly when comparing the first and third set of all exercises (Table 1). In addition, a greater number of repetitions were performed in each set for all exercises using a three-minute RI (Table 2) (Rodrigues, Rodrigues, Sandy, Filho \& Dantas, 2012). A possible limitation in the previous studies was the use of untrained subjects; current research suggests that resistance-trained men may benefit the most from longer RIs because they require a longer recovery period to prevent a decrease in the number of repetitions performed (Richmond \& Godard, 2004).

Miranda et al. (2009) included 12 healthy men with at least two years of recreational resistance training experience. The subjects performed five different upper-body resistance training exercises using an $8 \mathrm{RM}$ load (80\% of $1 \mathrm{RM})$ with either a one or three-minute RI between sets. The results showed significant differences in the repetitions completed during each exercise set for both RIs; however, the three-minute RI allowed for the greatest consistency in repetitions throughout all three sets (Table 1). Furthermore, significant differences were found in the number of repetitions completed during most exercise sets between both rest conditions (Table 2). The researchers concluded that instituting a longer RI (e.g., three-minutes) allowed for a greater amount and sustainability of repetitions compared to a shorter RI (e.g., one-minute).

Another possible limitation of all the aforementioned studies was the use of only fixed RIs between sets. Monteiro, Venturim, Perez, and Farinatti (2013) compared the effects of between set RIs using different methods of recovery. These methods included exerciserecovery ratios (1:3, 1:5, and 1:7), progressive intervals in each subsequent set (1:3-1:5-1:7-1:9), and a 2-minute fixed interval. The subjects included 16 men with at least one year of resistance training experience. All subjects performed five sets of the bench press and triceps extension using $80 \%$ of their 1RM load. The results showed that the shortest rest ratio $(1: 3)$ had the greatest decrease in the number of repetitions completed; although, all other strategies were also unable to sustain repetitions within multiple sets (Table 1). A similar study by Larson \& Potteiger (1997) also investigated the effects of different methods of recovery on the number of squat repetitions performed over four sets using $85 \%$ of subject's 10RM. RIs included a post-exercise heart rate of $60 \%$ age-predicted maximum heart rate, three-minute fixed interval, and a 1:3 rest ratio. No significant differences were found in the repetitions performed to exhaustion between 
all rest conditions (Table 2); however, no RI allowed for complete sustainability of repetitions throughout the consecutive sets (Table 1). Both studies concluded that the duration of the RI may be more influential than the strategy used to determine it.

Table 2. Maximum Repetitions Performed Each Set Using Various Rest Intervals

\begin{tabular}{|c|c|c|c|c|c|c|}
\hline Study & Load & $\begin{array}{l}\text { Exercises \& } \\
\text { Rest Intervals }\end{array}$ & Set 1 & Set 2 & Set 3 & Set 4 \\
\hline \multirow[t]{5}{*}{ Rodrigues et al. (2012) } & $80 \%$ of $1 R M$ & $\begin{array}{l}\text { Barbell bench press } \\
1 \mathrm{~min} \\
3 \mathrm{~min}\end{array}$ & $\begin{array}{l}5.8 \pm 2.3 \\
6.9 \pm 2.5\end{array}$ & $\begin{array}{l}3.6 \pm 1.5 \\
4.7 \pm 1.7^{*}\end{array}$ & $\begin{array}{l}2.8 \pm 1.2 \\
4.1 \pm 1.8^{*}\end{array}$ & \\
\hline & & $\begin{array}{l}\text { Machine lat pull down } \\
1 \mathrm{~min} \\
3 \mathrm{~min}\end{array}$ & $\begin{array}{l}6.9 \pm 2.0 \\
7.4 \pm 1.9\end{array}$ & $\begin{array}{l}3.6 \pm 1.1 \\
6.2 \pm 1.3^{*}\end{array}$ & $\begin{array}{l}2.9 \pm 1.0 \\
4.4 \pm 1.5^{*}\end{array}$ & \\
\hline & & $\begin{array}{l}\text { Seated machine shoulder } \\
\text { press } \\
1 \mathrm{~min} \\
3 \mathrm{~min}\end{array}$ & $\begin{array}{l}3.7 \pm 1.9 \\
4.5 \pm 2.7^{*}\end{array}$ & $\begin{array}{l}2.1 \pm 1.6 \\
2.7 \pm 1.8\end{array}$ & $\begin{array}{l}1.3 \pm 1.1 \\
2.3 \pm 1.7^{*}\end{array}$ & \\
\hline & & $\begin{array}{l}\text { Machine triceps extension } \\
1 \mathrm{~min} \\
3 \mathrm{~min}\end{array}$ & $\begin{array}{l}8.3 \pm 2.9 \\
9.9 \pm 2.7^{*}\end{array}$ & $\begin{array}{l}5.3 \pm 1.5 \\
7.6 \pm 2.5^{*} \\
\end{array}$ & $\begin{array}{l}3.8 \pm 1.0 \\
6.4 \pm 2.6^{*}\end{array}$ & \\
\hline & & $\begin{array}{l}\text { Free weight standing bicep } \\
\text { curl with straight bar } \\
1 \mathrm{~min} \\
3 \mathrm{~min}\end{array}$ & $\begin{array}{l}5.2 \pm 1.7 \\
5.6 \pm 1.6 \\
\end{array}$ & $\begin{array}{l}2.5 \pm 1.0 \\
4.4 \pm 1.2^{*}\end{array}$ & $\begin{array}{l}1.9 \pm 0.9 \\
3.1 \pm 1.1^{*}\end{array}$ & \\
\hline \multirow[t]{5}{*}{ Miranda et al. (2009) } & 8RM & $\begin{array}{l}\text { Barbell bench press } \\
1 \mathrm{~min} \\
3 \mathrm{~min}\end{array}$ & $\begin{array}{l}8.4 \pm 0.2 \\
8.3 \pm 0.2 \\
\end{array}$ & $\begin{array}{l}6.4 \pm 0.5 \\
7.3 \pm 0.5\end{array}$ & $\begin{array}{l}4.2 \pm 0.5 \\
5.9 \pm 1.0^{*}\end{array}$ & \\
\hline & & $\begin{array}{l}\text { Inclined bench press } \\
1 \mathrm{~min} \\
3 \mathrm{~min} \\
\end{array}$ & $\begin{array}{l}5.0 \pm 0.7 \\
7.3 \pm 0.5^{*}\end{array}$ & $\begin{array}{l}3.9 \pm 0.7 \\
6.6 \pm 0.5^{*}\end{array}$ & $\begin{array}{l}3.3 \pm 0.5 \\
6.1 \pm 0.7^{*} \\
\end{array}$ & \\
\hline & & $\begin{array}{l}\text { Peck deck fly } \\
1 \mathrm{~min} \\
3 \mathrm{~min}\end{array}$ & $\begin{array}{l}4.6 \pm 0.8 \\
6.8 \pm 0.4^{*}\end{array}$ & $\begin{array}{l}3.8 \pm 0.7 \\
5.9 \pm 0.7^{*}\end{array}$ & $\begin{array}{l}3.3 \pm 0.8 \\
5.3 \pm 0.8^{*}\end{array}$ & \\
\hline & & $\begin{array}{l}\text { Barbell lying triceps extension } \\
1 \mathrm{~min} \\
3 \mathrm{~min}\end{array}$ & $\begin{array}{l}6.5 \pm 0.91 \\
7.3 \pm 0.65 \\
\end{array}$ & $\begin{array}{l}4.9 \pm 0.9 \\
6.6 \pm 0.7\end{array}$ & $\begin{array}{l}3.4 \pm 1.0 \\
6.0 \pm 0.7^{*}\end{array}$ & \\
\hline & & $\begin{array}{l}\text { Triceps pushdown } \\
1 \mathrm{~min} \\
3 \mathrm{~min} \\
\end{array}$ & $\begin{array}{l}4.8 \pm 0.6 \\
6.1 \pm 0.7 \\
\end{array}$ & $\begin{array}{l}3.1 \pm 0.8 \\
5.3 \pm 0.7^{*}\end{array}$ & $\begin{array}{l}2.0 \pm 0.7 \\
4.9 \pm 0.6^{*}\end{array}$ & \\
\hline Larson \& Potteiger (1997) & $85 \%$ of $10 R M$ & $\begin{array}{l}\text { Squat } \\
\text { Post HR } \\
3 \text { min } \\
\text { Ratio 1:3 }\end{array}$ & $\begin{array}{l}15.7 \pm 0.7 \\
15.5 \pm 0.6 \\
15.6 \pm 0.7\end{array}$ & $\begin{array}{l}10.6 \pm 0.5 \\
10.7 \pm 0.7 \\
10.9 \pm 0.8\end{array}$ & $\begin{array}{l}8.8 \pm 0.4 \\
8.1 \pm 0.4 \\
8.3 \pm 0.6\end{array}$ & $\begin{array}{l}7.9 \pm 0.6 \\
6.5 \pm 0.5 \\
6.8 \pm 0.6\end{array}$ \\
\hline \multirow[t]{2}{*}{ Dias et al. (2014) } & 10RM & $\begin{array}{l}\text { Peck deck fly } \\
1 \mathrm{~min} \\
2 \mathrm{~min}\end{array}$ & $\begin{array}{l}10.0 \pm 0.0 \\
10.0 \pm 0.0\end{array}$ & $\begin{array}{l}7.9 \pm 2.1 \\
8.4 \pm 2.1\end{array}$ & $\begin{array}{l}4.9 \pm 1.9 \\
6.4 \pm 1.8\end{array}$ & \\
\hline & & $\begin{array}{l}\text { Bench press } \\
1 \mathrm{~min} \\
2 \mathrm{~min}\end{array}$ & $\begin{array}{l}10.5 \pm 1.1 \\
11.2 \pm 1.5\end{array}$ & $\begin{array}{l}5.7 \pm 2.8 \\
7.9 \pm 2.4^{*}\end{array}$ & $\begin{array}{l}3.3 \pm 2.2 \\
5.2 \pm 2.9^{*}\end{array}$ & \\
\hline Richmond \& Godard (2004) & $75 \%$ of $1 R M$ & $\begin{array}{l}\text { Bench press } \\
1 \mathrm{~min} \\
3 \mathrm{~min} \\
5 \mathrm{~min}\end{array}$ & $\begin{array}{l}11.9 \pm 2.5 \\
11.5 \pm 2.2 \\
11.5 \pm 2.3\end{array}$ & $\begin{array}{l}5.5 \pm 2.2 \\
8.3 \pm 2.6^{*} \\
9.7 \pm 2.4^{*}\end{array}$ & & \\
\hline
\end{tabular}

Note. ${ }^{*}=$ set significantly different between all rest intervals.

Dias et al. (2014) used a different approach to test the effects of RI duration during upper-body resistance training. The purpose of the study was to compare the differences in the number of repetitions completed during a uni-joint (peck deck fly) or multi-joint (bench press) exercise. This randomized study included 18 healthy resistance-trained men $(23.4 \pm 3.5 \mathrm{yrs})$ who performed three sets of a $10 \mathrm{RM}$ load using either a one-minute or two-minute RI between sets for both exercises. The results showed a greater number of repetitions performed during the third set of the peck deck fly exercise when using a two-minute RI compared to a one-minute RI (Table 2). Similarly, a two- 
minute RI allowed for a significantly greater number of repetitions performed during the second and third set of the bench press exercise (Table 2). The study concluded multi-joint exercises, such as the bench press, may benefit the most from longer RIs in regard to the maximum number of repetitions performed during each set.

Corroborating research conducted by Richmond \& Godard (2004), investigated the effects of three different between-set RIs (1-min vs 3-min vs 5-min) on multi-joint resistance training performance. Subjects were comprised of 28 healthy resistance-trained males who performed two sets of the bench press exercise using $75 \%$ of their $1 \mathrm{RM}$ load. The results indicated that repetitions significantly decreased between the first and second set for all resting periods (Table 1). In addition, the repetitions performed during the second set for all rest conditions were significantly different between groups (Table 2). The study concluded that the prescribed recovery between sets did not prevent a decrease in the number of repetitions; however, the three and five-minute RIs allowed for a greater sustainability of repetitions as sets progressed. The longer RIs were determined to be the most beneficial because they allowed targeted muscle groups a longer recovery period to resynthesize energy substrates (Harris et al., 1979; Richmond \& Godard, 2004).

Finally, research performed by Mirzaei et al. (2008) investigated the effects of different RIs on the sustainability of repetitions when using either a heavy or light resistance load. The study included 17 resistance-trained men who performed four consecutive sets of a bench press using two different loads (60\% vs $90 \%$ of $1 \mathrm{RM})$ and three different RIs (1.5-min vs 2.5-min vs 4-min). The results of the study demonstrated that the longest RI (4-min) resulted in a greater sustainability of repetitions when compared to the shorter RIs (1.5-min vs 2.5-min) for both training loads (Table 1). Furthermore, sustainability of repetitions over four consecutive sets were significantly greater for the heavier training load (90\%). This study concluded that longer RIs highly influence the number of repetitions performed, particularly during upper-body resistance training with heavy loads.

\section{Training Volume}

As previously mentioned, a longer RI has the greatest effect on the number and sustainability of repetitions over consecutive sets during a resistance training session. The sustainability of repetitions can allow for greater training volume (repetitions $\times$ sets $\times$ load), which prompts gains in muscular strength (Willardson \& Burkett, 2008). Prior investigations have suggested the use of a longer duration of rest between sets, particularly when the training goal requires a heavy training load and a large amount of training volume (Ratamess et al., 2007). A previously mentioned study by Dias et al. (2014) compared differences between the training volume completed during uni-joint (peck deck fly) and multi-joint (bench press) exercises using either a one or two-minute RI between sets of a 10RM load. The study reported longer RIs (2-min) allowed for a greater training volume completed for both the uni-joint and multi-joint exercises (Table 3). To contribute to the findings of Dias et al. (2014), a study performed by Willardson and Burkett (2005) investigated the effects of one, two, and fiveminute RIs on squat and bench press training volume. A group of 15 resistance-trained men performed four sets of a squat and bench press exercise using an $8 \mathrm{RM}$ load (85\% of $1 \mathrm{RM})$ and three different between-set RIs. The results showed that total training volume completed was significantly different between all RIs for both exercises, but the five-minute RI allowed for the greatest amount of volume to be completed (Table 3). Similar results were reported during a four-week study consisting of a 10RM bench press exercise using one, three, and five-minute RIs (Table 3) (Richmond \& Godard, 2004).

To determine an optimal resting duration, Ratamess et al. (2007) tested multiple RI lengths to examine and quantify the total training volume completed during the bench press exercise. This eight-week study included eight healthy resistance trained men. Subjects performed either a 10RM or 5RM load during the bench press exercise using five different RIs between sets (i.e., 30s, 1, 2, 3, 5-min). Training volume significantly decreased over four consecutive sets between all rest conditions except with the use of a five-minute RI (Table 3). A similar study investigated the total training volume completed during multiple upper-body resistance exercises using either a one or three-minute RI. The results also highlighted the linear relationship between RI duration and total training volume completed during an upper-body resistance training session (Table 3) (Miranda et al., 2009). The results of aforementioned studies determined longer RIs were the most beneficial to significantly increase training volume; however, a study conducted by Monteiro et al. (2013) found no significant differences in training volume after subjects rested between two and five-minutes between sets while performing both the triceps extension and bench press using $80 \%$ of subject's 1RM load (Table 3). A possible causation for conflicting results may be the duration of the experimental procedure. Reports of acute responses due to RI manipulations have been inconsistent due to varied methodologies; therefore, chronic response research might infer more conclusive results regarding the effects of RI duration on training volume.

De Souza Jr. et al. (2010) was the first study to compare the chronic effects of decreasing (2-min to 30s) and constant (2-min) RIs during an eight-week resistance training program. Twenty resistance trained males were equally divided into either a decreasing or constant RI group and performed two different training programs. During the first two weeks, three sets of 10-12RM load were performed for various upper-body and midsection exercises using two-minute RIs between sets. After the first two weeks, the constant RI group continued the same protocol while the descending RI group implemented decreasing RIs between sets (2min- 30secs). The results highlighted that the total training volume completed for both the squat and leg press were significantly greater in the constant RI group when compared to the descending RI group after the eight-week experimental treatment (Table 3).

Lastly, another study by Willardson and Burkett (2008) reported consistent results with De Souza Jr. et al. (2010). The researchers used four mesocycles (three-week periods) to compare training volume for 15 resistance trained men using both a heavy (70 - 90\% $1 \mathrm{RM})$ and light $(60 \% 1 \mathrm{RM})$ resistance load for the squat exercise. Subjects were prescribed two and four-minute RIs and asked to perform between five and eight sets for all exercises until exhaustion. The data indicated that a significantly greater training volume was completed during the heavy workouts (70-90\% of $1 \mathrm{RM}$ ) when a four-minute RI was used (Table 3). An investigation by De Salles et al. (2010) also suggested training volume was significantly greater when a longer RI was prescribed for both upper and lower-body exercises (Table 3). The major finding of all studies was training volume increased proportionally as the RI duration increased during resistance exercises using heavy loads. 
Table 3. Total Training Volume Completed Using Various Rest Intervals

\begin{tabular}{|c|c|c|c|c|c|}
\hline Study & Subjects & Duration & Intervention & Intervals & Results \\
\hline Dias et al. (2014) & $\begin{array}{l}18 \text { trained men } \\
(23.4 \pm 3.5 \text { yrs. })\end{array}$ & 2 weeks & $\begin{array}{l}2 \text { experimental sessions: } \\
\text { - } \quad \text { Bench press } \\
\text { - } \quad \text { Peck deck fly } \\
\text { - } \quad 3 \text { sets 10RM }\end{array}$ & $\begin{array}{l}1 \mathrm{~min} \\
2 \mathrm{~min}\end{array}$ & $\begin{array}{l}\text { Total training volume significantly } \\
\text { greater for both exercises using } 2 \\
\text { min rest interval }\end{array}$ \\
\hline $\begin{array}{l}\text { Willardson \& Burkett } \\
\text { (2005) }\end{array}$ & $\begin{array}{l}15 \text { trained men } \\
(20.7 \pm 2.6 \text { yrs. })\end{array}$ & $\sim 4$ weeks & $\begin{array}{ll}3 \text { experimental sessions } \\
\text { - } & \text { Bench press } \\
\text { - } & \text { Squat } \\
\text { - } & 4 \text { sets 8RM }\end{array}$ & $\begin{array}{l}1 \mathrm{~min} \\
2 \mathrm{~min} \\
5 \mathrm{~min}\end{array}$ & $\begin{array}{l}\text { Total training volume significantly } \\
\text { different between all rest intervals } \\
\text { for both exercises }\end{array}$ \\
\hline $\begin{array}{l}\text { Richmond \& Godard } \\
\text { (2004) }\end{array}$ & $\begin{array}{l}28 \text { trained men } \\
(21.5 \pm 3.2 \text { yrs. })\end{array}$ & $\sim 4$ weeks & $\begin{array}{l}\text { 3 experimental sessions: } \\
\text { - } \quad \text { Bench press } \\
\text { - } \\
75 \% \text { of } 1 \mathrm{RM}\end{array}$ & $\begin{array}{l}1 \mathrm{~min} \\
3 \mathrm{~min} \\
5 \mathrm{~min}\end{array}$ & $\begin{array}{l}\text { Training volume performed in } 2^{\text {nd }} \\
\text { set significantly different between } \\
\text { all rest intervals }\end{array}$ \\
\hline Ratamess et al. (2007) & $\begin{array}{l}8 \text { trained men } \\
(21.4 \pm 2.4 \text { yrs. })\end{array}$ & $\sim 8$ weeks & $\begin{array}{l}\text { 5 experimental sessions per week } \\
\text { - } \quad \text { Bench press } \\
\text { Alternating: } \\
-\quad 75 \% \text { of } 1 \mathrm{RM} \\
\text { - } \quad 85 \% \text { of } 1 \mathrm{RM}\end{array}$ & $\begin{array}{l}30 \mathrm{sec} \\
1 \mathrm{~min} \\
2 \mathrm{~min} \\
3 \mathrm{~min} \\
5 \mathrm{~min}\end{array}$ & $\begin{array}{l}\text { Training volume significantly } \\
\text { decreased as sets progressed for all } \\
\text { rest intervals except } 5 \text { min interval }\end{array}$ \\
\hline Miranda et al. (2009) & $\begin{array}{l}12 \text { trained men } \\
(23.6 \pm 2.5 \text { yrs. })\end{array}$ & $\sim 4$ weeks & $\begin{array}{l}\text { 2 experimental sessions: } \\
\text { - } \quad \text { Barbell bench press } \\
\text { - } \quad 3 \text { sets 8RM }\end{array}$ & $\begin{array}{l}1 \mathrm{~min} \\
3 \mathrm{~min}\end{array}$ & $\begin{array}{l}\text { Significantly greater training } \\
\text { volume completed for exercises } \\
\text { using } 3 \text { min rest interval }\end{array}$ \\
\hline Monteiro et al. (2013) & $\begin{array}{l}16 \text { trained men } \\
(25.0 \pm 2.5 \text { yrs. })\end{array}$ & $\sim 4$ weeks & \begin{tabular}{ll}
\multicolumn{2}{l}{5 experimental sessions: } \\
- & Bench press \\
- & Triceps extension \\
- & 5 sets $80 \% 1 \mathrm{RM}$
\end{tabular} & $\begin{array}{l}\text { Ratio 1:3 } \\
\text { Ratio 1:5 } \\
\text { Ratio 1:7 } \\
\text { IP } 2 \text { min }\end{array}$ & $\begin{array}{l}\text { No significant differences in } \\
\text { training volume between rest } \\
\text { intervals }\end{array}$ \\
\hline $\begin{array}{l}\text { De Souza et al. } \\
(2010)\end{array}$ & $\begin{array}{l}20 \text { trained men } \\
\text { CI: } 2 \text { min } \\
(20.5 \pm 1.0 \text { yrs. }) \\
\text { DI: } 2 \text { min }-30 \mathrm{~s} \\
(22.0 \pm 4.8 \text { yrs. })\end{array}$ & 8 weeks & 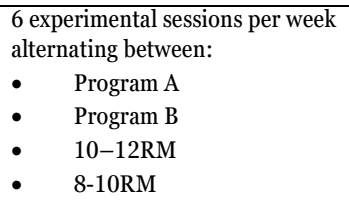 & $\begin{array}{l}\text { CI: } 2 \text { min } \\
\text { DI: } 2 \text { min } \\
-30 \mathrm{sec}\end{array}$ & $\begin{array}{l}\text { Total training volume significantly } \\
\text { greater for CI group compared to } \\
\text { DI group for both bench press and } \\
\text { squat exercises }\end{array}$ \\
\hline $\begin{array}{l}\text { Willardson \& Burkett } \\
\text { (2008) }\end{array}$ & $\begin{array}{l}15 \text { trained men } \\
2 \text { min } \\
(20.7 \pm 1.4 \text { yrs. }) \\
4 \text { min } \\
(22.6 \pm 4.6 \text { yrs. })\end{array}$ & $\sim 16$ weeks & $\begin{array}{ll}3 \text { mesocycles (4 weeks): } \\
\text { - } \quad \text { Squat } \\
\text { Alternating: } \\
-\quad \begin{array}{l}\text { Heavy workouts } \\
(70 \%-90 \% \text { of } 1 \mathrm{RM})\end{array} \\
\begin{array}{l}\text { Light workouts } \\
(60 \% \text { of } 1 \mathrm{RM})\end{array}\end{array}$ & $\begin{array}{l}2 \mathrm{~min} \\
4 \mathrm{~min}\end{array}$ & $\begin{array}{l}\text { Total training volume completed } \\
\text { significantly different between 2- } \\
\text { and 4-min rest interval }\end{array}$ \\
\hline De Salles et al. (2010) & $\begin{array}{l}36 \text { trained men } \\
\text { 1-min: } \\
(22.4 \pm 1.3 \text { yrs. }) \\
\text { 3-min: } \\
(22.3 \pm 1.0 \text { yrs. }) \\
5 \text {-min: } \\
(22.3 \pm 1.0 \text { yrs. })\end{array}$ & 16 weeks & 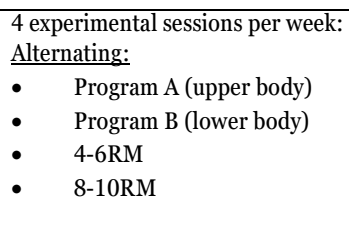 & $\begin{array}{l}1 \mathrm{~min} \\
3 \mathrm{~min} \\
5 \mathrm{~min}\end{array}$ & $\begin{array}{l}\text { Total training volume significantly } \\
\text { greater for groups using } 3 \text { min and } \\
5 \text { min rest intervals compared to } 1 \\
\text { min rest interval (bench press plus } \\
\text { leg press) }\end{array}$ \\
\hline
\end{tabular}

Note. $\mathrm{RM}=$ Repetition Maximum. IP = Progressive Interval. $\mathrm{CI}=$ Constant Rest Interval. DI = Decreasing Rest Interval.

\section{Strength Gains}

Prior research suggests a greater number repetitions and a greater amount of training volume lead to increases in muscular strength; however, contradictory research indicates that the duration of the RI may not affect overall strength (Willardson \& Burkett, 2008). Such results were found in the study conducted by Gentil et al (2010). The researchers performed a longitudinal study to investigate the chronic effects of two different between-set rest ratios (1:3 vs 1:6) on muscle strength (Final 1RM load) in 32 non-resistance trained young men. The subjects were prescribed a 12-week whole-body resistance training program comprised of two upper body exercises, two lower body exercises, and one midsection exercise. All exercises included either rest ratio (1:3 vs 1:6) between sets with an 8-12RM load. The results 
showed that the 1RM load significantly increased from pre-treatment to post-treatment following the 12-week resistance training intervention regardless of the rest ratio employed (Table 4).

Table 4. Strength Increases Using Various Rest Intervals

\begin{tabular}{|c|c|c|c|c|c|}
\hline Study & Subjects & Duration & Intervention & Intervals & Results \\
\hline Gentil et al. (2010) & $\begin{array}{l}32 \text { untrained men } \\
\text { Long rest }(1: 6) \\
(22.4 \pm 2.6 \text { yrs.) } \\
\text { Short rest }(1: 3) \\
(21.4 \pm 3.2 \text { yrs.) }\end{array}$ & $\sim 16$ weeks & $\begin{array}{l}3 \text { programs (12weeks) } \\
-\quad 2 \text { upper body exercises } \\
\text { - } \quad 2 \text { lower body exercises } \\
\text { - } \quad 1 \text { midsection exercise } \\
\quad 2 \text { sets } 8-12 \text { RM }\end{array}$ & $\begin{array}{l}1: 3 \\
1: 6\end{array}$ & $\begin{array}{l}\text { Similar and significant increases in } \\
\text { upper and lower body strength no } \\
\text { matter what rest ratio was used }\end{array}$ \\
\hline $\begin{array}{l}\text { Buresh, Berg, \& French } \\
\text { (2009) }\end{array}$ & $\begin{array}{l}12 \text { untrained men } \\
(24.8+5.9 \text { yrs. })\end{array}$ & 10 weeks & $\begin{array}{l}\text { 4 experimental sessions per week: } \\
-\quad \text { Bench Press } \\
\text { - Squat } \\
\text { Alternating: } \\
\text { - Session } 1 \text { (lower body) } \\
\text { Session } 2 \text { (upper body) }\end{array}$ & $\begin{array}{l}1 \mathrm{~min} \\
2.5 \mathrm{~min}\end{array}$ & $\begin{array}{l}\text { There was no difference between } \\
\text { groups in relative strength increase } \\
\text { in either the squat or bench press. }\end{array}$ \\
\hline De Salles et al. (2010) & $\begin{array}{l}36 \text { trained men } \\
1 \text {-min: } \\
(22.4 \pm 1.3 \text { yrs. }) \\
\text { 3-min: } \\
(22.3 \pm 1.0 \text { yrs. }) \\
5 \text {-min: } \\
(22.3 \pm 1.0 \text { yrs. })\end{array}$ & 16 weeks & $\begin{array}{l}\text { 4 experimental sessions } \\
\text { Alternating: } \\
\text { - } \quad \text { Program A (upper body) } \\
\text { - } \quad \text { Program B (lower body) } \\
\text { Alternating: } \\
\text { - } \quad \text { 4-6RM } \\
\text { - } \quad \text { 8-10RM }\end{array}$ & $\begin{array}{l}1 \mathrm{~min} \\
3 \mathrm{~min} \\
5 \mathrm{~min}\end{array}$ & $\begin{array}{l}\text { Bench press group that used } 5 \text { min } \\
\text { rest intervals were significantly } \\
\text { stronger when compared to the } 1 \\
\text { min group. }\end{array}$ \\
\hline $\begin{array}{l}\text { Willardson \& Burkett } \\
\text { (2008) }\end{array}$ & $\begin{array}{l}15 \text { trained men } \\
2 \text { min } \\
(20.7+1.4 \text { yrs. }) \\
4 \text { min } \\
(22.6+4.6 \text { yrs. })\end{array}$ & $\sim 16$ weeks & $\begin{array}{ll}3 \text { mesocycles (4 weeks): } \\
\text { - } \quad \text { Squat } \\
\text { Alternating: } \\
-\quad \text { Heavy workouts } \\
\quad \text { (70\% - } 90 \% \text { of } 1 \mathrm{RM}) \\
\text { - } \quad \text { Light workouts } \\
\quad(60 \% \text { of } 1 \mathrm{RM})\end{array}$ & $\begin{array}{l}2 \min \\
4 \mathrm{~min}\end{array}$ & $\begin{array}{l}\text { No significant difference in squat } \\
\text { strength gains between groups that } \\
\text { used 2- and 4-min rest intervals }\end{array}$ \\
\hline
\end{tabular}

Note. $\mathrm{RM}=$ Repetition Maximum.

A similar study by Buresh, Berg, and French (2009) compared the effects of two different RIs (1 vs 2.5-min) on strength gains obtained from a whole-body resistance training program. Twelve untrained men were randomly divided into two separate groups (short rest vs. long rest). Subjects participated in four training sessions per week, for ten weeks, of an alternating upper and lower-body training program. Subject's baseline and post-training 1RM values were used to determine strength increases. No significant differences were found between groups in relative strength in either the squat or bench press exercise (Table 4). A possible limitation from the previously mentioned studies was the use of non-resistance trained individuals. Untrained subjects acquire strength increases no matter what type of RI was used due to no previous neuromuscular adaptations (Baechle \& Earle, 2016).

De Salles et al. (2010) performed a longitudinal study to determine the influence of different RIs on upper-body strength increases in 36 resistance trained men during a 16-week exercise regimen. The subjects prescribed either a 1-min, 3-min, or 5-min RI treatment during a bench press exercise. The results indicated that the group that used a 5-min RI were significantly stronger when compared to the 1-min group (Table 4). The researchers concluded that longer RIs between sets may contribute to greater strength increases. Conversely, a similar longitudinal study using resistance trained men found no significant differences in squat strength gains between groups that used either two or four-minute RI between sets (Table 4) (Willardson \& Burkett, 2008). A consensus of previous research suggests muscular strength gains may not be affected by the duration of rest between sets.

\section{CONCLUSION}

The recommended rest duration between sets consists of using either a short ( $\sim 30 \mathrm{~s}-2$-min) or long ( $2-5$-min) RI based on an individual's resistance training goal (Haff \& Triplett, 2016). Prior investigations in RI effects have suggested the use of longer RIs during training with a heavy load because they allowed for a greater amount of time to resynthesize energy substrates and remove metabolic waste (Kraemer \& Fleck, 2007; Harris et al, 1976). Furthermore, longer RIs were the most successful at sustaining and increasing the repetitions performed (Richmond \& Godard, 2004). The population most affected by longer RIs was resistance-trained men, specifically during multijoint exercises with a heavy training load (Dias et al., 2014; Faigenbaum et al., 2008; Mirzaei, Arazi, \& Saberi, 2008).

Increasing the maximum number of repetitions performed leads to a greater training volume completed during an exercise session. In prior research, subjects overall training volume was the most affected by longer RIs (Miranda et al., 2009). The most reliable results of the 
linear relationship between RI duration and training volume was found in studies that observed chronic effects with longer experimental treatments (De Souza Jr. et al., 2010; Willardson\& Burkett, 2008). The only inconclusive results of RI manipulation were studies that investigated muscular strength adaptations (Buresh, Berg, \& French, 2009). The results showed a possible link between longer rest between and strength gains, but a consensus from the literature suggests further longitudinal research may be needed (De Salles et al., 2010; Gentil et al, 2010; Willardson \& Burkett, 2008).

Despite certain findings, none of the RIs prescribed to subjects allowed for the complete maintenance of repetitions throughout sets, which ultimately affects the training volume completed (reps $\times$ sets $\times$ load). This lead the researchers in the aforementioned studies to conclude that further research is needed on RIs longer than five minutes, possibly eight minutes (Haff \& Triplett, 2016; Harris et al., 1976), to see if there are any further contributions to resistance training performance, specifically in repetition performance and the volume of training completed.

\section{REFERENCES}

American College of Sports Medicine (ACSM). Progression models in resistance training for healthy adults. (2009). Medicine \& Science in Sports \& Exercise, 41(3), 687-708. doi: 10.1249/mss.0b013e3181915670

Buresh, R., Berg, K., \& French, J. (2009). The effect of resistive exercise rest interval on hormonal response, strength, and hypertrophy with training. Journal of Strength and Conditioning Research, 23(1), 62-71. doi: 10.1519/jsc.0b013e318185f14a

Dias, M.R.C., de Matos, D.G., Mazini, Filho M.L., Moreira, O.C., Hickner, R.C., Cardozo, D., Alves, H.B., Reis, L.G., \& Aidar, F.J. (2014). Comparison of repetition number between uni-joint and multi-joint exercises with 1-min and 2-min rest intervals. $J$ Exerc Physiol Online, 17(4), 93-101. Retrieved from: https://www.asep.org/asep/asep/JEPonlineAUGUST2014_Matos.pdf

Donnelly, J. E., Blair, S. N., Jakicic, J. M., Manore, M. M., Rankin, J. W., \& Smith, B. K. (2009). Appropriate physical activity intervention strategies for weight loss and prevention of weight regain for adults. Medicine \& Science in Sports \& Exercise, 41(2), 459-471. doi: 10.1249/mss.0b013e3181949333

Evangelista, R., Pereira, R., Hackney, A. C., \& Machado, M. (2011). Rest interval between resistance exercise sets: Length affects volume but not creatine kinase activity or muscle soreness. International Journal of Sports Physiology and Performance, 6(1), 118-127. doi: 10.1123/ijspp.6.1.118

Faigenbaum, A. D., Ratamess, N. A., Mcfarland, J., Kaczmarek, J., Coraggio, M. J., Kang, J., \& Hoffman, J. R. (2008). Effect of rest interval length on bench press performance in boys, teens, and men. Pediatric Exercise Science, 20(4), 457-469. doi: 10.1123/pes.20.4.457

Gentil, P., Bottaro, M., Oliveira, E., Veloso, J., Amorim, N., Saiuri, A., \& Wagner, D. R. (2010). Chronic effects of different between-set rest durations on muscle strength in nonresistance trained young men. Journal of Strength and Conditioning Research, 24(1), 3742. doi: 10.1519/jsc.0b013e3181b2965c

Haff, G., \& Triplett, N. T. (2016). Essentials of strength training and conditioning (4th ed.). Champaign, IL: Human Kinetics.

Harris, R. C., Edwards, R. H. T., Hultman, E., Nordesjö, L. O., Nylind, B., \& Sahlin, K. (1976). The time course of phosphorylcreatine resynthesis during recovery of the quadriceps muscle in man. Pflugers Archiv, 367(2), 137-142. https://doi.org/10.1007/bf00585149

Jan, M.H., Lin, J.J., Liau, J.J., Lin, Y.F., \& Lin, D.H. (2008). Investigation of clinical effects of high- and low-resistance training for patients with knee osteoarthritis: A randomized controlled trial. Physical Therapy, 88(4), 427-436. doi: 10.2522/ptj.20060300

Kenney, W. L., Wilmore, J. H., \& Costill, D. L. (2015). Physiology of sport and exercise. Champaign, IL: Human Kinetics.

Kraemer, W. J. (1997). A series of studies: The physiological basis for strength training in American football. Journal of Strength and Conditioning Research, 11(3), 131-142. doi: 10.1519/00124278-199708000-00001

Kraemer, W, \& Fleck, S. (2007). Optimizing strength training: Designing nonlinear periodization workouts. Champaign, IL: Human Kinetics.

Larson, G. D., \& Potteiger, J. A. (1997). A comparison of three different rest intervals between multiple squat bouts. Journal of Strength and Conditioning Research, 11(2), 115-118. doi: 10.1519/00124278-199705000-00011

Miranda, H., Simão, R., Moreira, L.M., de Souza, R.A., de Souza, J.A., de Salles, B.F., \& Willardson, J. M. (2009). Effect of rest interval length on the volume completed during upper body resistance exercise. J Sports Sci Med, 1(8): 388-392, 2009. Retrieved from: https://www.ncbi.nlm.nih.gov/pubmed/24150002

Mirzaei, B., Arazi, H., \& Saberi, Y. (2008). The effect of different rest intervals on sustainability of bench press repetitions with heavy vs light loads. International journal of fitness, 4(2): 9-16.

Monteiro, W. D., Venturim, F. O., Perez, A. J., \& Farinatti, P. T. (2013). Work volume in strength training is not affected by rest interval strategy. The Journal of sports medicine and physical fitness, 53(3), 312-318. Retrieved from: https://www.minervamedica.it/en/journals/sports-med-physical-fitness/article.php?cod=R40Y2013N03A0312\&acquista=1

Progression Models in Resistance Training for Healthy Adults. (2002). Medicine and Science in Sports and Exercise, 34(2), 364-380. doi: 10.1097/00005768-200202000-00027

Ratamess, N. A., Falvo, M. J., Mangine, G. T., Hoffman, J. R., Faigenbaum, A. D., \& Kang, J. (2007). The effect of rest interval length on metabolic responses to the bench press exercise. European Journal of Applied Physiology, 100(1), 1-17. https://doi.org/10.1007/s00421-007-0394-y

Richmond, S. R., \& Godard, M. P. (2004). The effects of varied rest periods between sets to failure using the bench press in recreationally trained men. Journal of Strength and Conditioning Research, 18(4), 846-849. doi: 10.1519/00124278-200411000-00028 
Robergs, R. A., Ghiasvand, F., \& Parker, D. (2004). Biochemistry of exercise-induced metabolic acidosis. American Journal of Physiology-Regulatory, Integrative and Comparative Physiology, 287(3), R502-R516. https://doi.org/10.1152/ajpregu.00114.2004

Rodrigues, B. M., Rodrigues, A. M., Sandy, D. D., Filho, M. M., \& Dantas, E. M. (2012). The effect of two different rest intervals on the number of repetitions in a training session. Serb $J$ Sports Sci, (1), 37-41.

Retrieved from: https://www.sjss.sportsacademy.edu.rs/archive/number/2012-1

Salles, B. F. D., Simão, R., Miranda, F., Novaes, J. D. S., Lemos, A., \& Willardson, J. M. (2009). Rest interval between sets in strength training. Sports Medicine, 39(9), 765-777. doi: 10.2165/11315230-000000000-00000

Souza, T. P. D., Fleck, S. J., Simão, R., Dubas, J. P., Pereira, B., Pacheco, E. M. D. B., ... Oliveira, P. R. D. (2010). Comparison between constant and decreasing rest intervals: Influence on maximal strength and hypertrophy. Journal of Strength and Conditioning Research, 24(7), 1843-1850. doi: 10.1519/jsc.0b013e3181ddae4a

Weiss, L. W. (1991). The obtuse nature of muscular strength: The contribution of rest to its development and expression. The Journal of Strength and Conditioning Research, 5(4), 219-227. doi: 10.1519/1533-4287(1991)005<0219:tonoms>2.3.c0;2

Willardson, J. M., \& Burkett, L. N. (2005). A comparison of 3 different rest intervals on the exercise volume completed during a workout. The Journal of Strength and Conditioning Research, 19(1), 23. doi: 10.1519/r-13853.1

Willardson, J. M. (2006). A brief review: Factors affecting the length of the rest interval between resistance exercise sets. The Journal of Strength and Conditioning Research, 20(4), 978. doi: 10.1519/r-17995.1

Willardson, J. M., \& Burkett, L. N. (2008). The effect of different rest intervals between sets on volume components and strength gains. Journal of Strength and Conditioning Research, 22(1), 146-152. doi: 10.1519/jsc.0b013e31815f912d

\section{Author Information}

Dennis J. Hernandez, DPT.

(D) https://orcid.org/0000-0002-5429-7562

Department of Physical Therapy

D’Youville College, Buffalo, NY, USA

@ hernad09@dyc.edu
Young Sub Kwon, Ph.D., Corresponding Author (1) https://orcid.org/0000-0001-8920-2757

Associate Professor \& Director of Human Performance Lab Department of Kinesiology and Recreation Administration College of Professional Studies

California Polytechnic University, Humboldt, Arcata, CA, USA

@ young.kwon@humboldt.edu

Conflict of Interest: The authors declare that the research was conducted in the absence of any commercial or financial relationship that could be constructed as a potential conflict of interest.

Publisher's Note: All claims expressed in this article are solely those of the authors and do not necessarily represent those of their affiliated organizations, or those of the publisher, the editors and reviewers. Any product that may be evaluated in this article, or claim that may be made by its manufacturer, is not guaranteed or endorsed by the publisher. 